\title{
Pengaruh Persepsi Kegunaan dan Kemudahan Penggunaan Pada Minat Penggunaan Quick Response Code dalam Transaksi Keuangan
}

\author{
Nabilah Aulia ${ }^{1}$ \\ Fakultas Ekonomi dan Bisnis \\ Universitas Udayana, Indonesia. \\ Email: nab.aulia12@gmail.com
}

\author{
I Ketut Suryanawa ${ }^{2}$ \\ Fakultas Ekonomi dan Bisnis \\ Universitas Udayana, Indonesia.
}

\begin{abstract}
ABSTRAK
Penelitian kali ini dilakukan pada mahasiswa program studi Akuntansi FEB Universitas Udayana angkatan 2015-2018 yang masih aktif. Sampel sejumlah 294 mahasiswa. Teknik penentuan sampel adalah sampling insidental. Tujuan untuk mengetahui pengaruh persepsi kegunaan dan persepsi kemudahan penggunaan pada minat mahasiswa Akuntansi FEB Universitas Udayana dalam menggunakan QR Code dalam transaksi keuangan. Hasil penelitian dapat diketahui bahwa terdapat pengaruh langsung antara persepsi kemudahan penggunaan pada persepsi kegunaan dan juga terdapat pengaruh langsung antara persepsi kemudahan penggunaan pada minat penggunaan. Dalam penelitian ini juga diperoleh hasil tidak terdapat pengaruh langsung antara persepsi kegunaan pada minat penggunaan dan tidak terdapat pengaruh antara persepsi kemudahan penggunaan pada minat penggunaan melalui persepsi kegunaan sebagai pemediasi.
\end{abstract}

Kata Kunci Persepsi kegunaan, Persepsi kemudahan penggunaan, Minat penggunaan, QR Code.

The Influence of Perception of Use and Ease of Use on Interest in Using the Quick Response Code in Financial Transactions

\section{ABSTRACT}

This research was conducted on students of the Accounting Department of FEB, Udayana University, 2015 -2018 who are still active. A sample of 294 students. The sampling technique is incidental sampling. The aim is to determine the effect of perceived usefulness and perceived ease of use on the interest of FEB Accounting Students at Udayana University in using the QR Code in financial transactions. The results of the study can be seen that there is a direct influence between the perceived ease of use on the perception of usability and also there is a direct influence between the perceived ease of use in interest in use. In this study also obtained results that there is no direct influence between perceived usefulness in interest in use and there is no influence between perceptions of ease of use in interest in use through the perception of usability as a mediator.

Keywords: Perception of usability, Perception of ease of use, interest in use, $Q R$ Code.

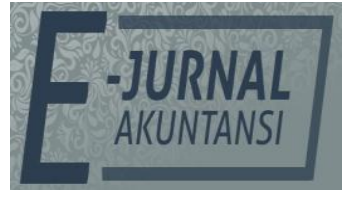

E-JA

e-Jurnal Akuntansi

e-ISSN 2302-8556

Denpasar,

Vol. 28 No. 3

September 2019

Hal. 1749-1766

Artikel masuk:

15 April 2019

Tanggal diterima:

26 Mei 2019 


\section{PENDAHULUAN}

Revolusi industri 4.0 pada bidang ekonomi difokuskan untuk menggerakkan dan mengembangkan digital economy. Sistem pembayaran digital saat ini sudah tidak lagi menggunakan uang tunai. Transformasi pembayaran menggunakan uang digital menjadi solusi baru yang inovatif saat penggunaan uang tunai dirasa kurang efektif dan dapat memicu tingkat kriminalitas. Sejalan dengan hal tersebut Gubernur Bank Indonesia, Agus D.W. Marto Wardjojo, secara resmi mencanangkan Gerakan Nasional Non Tunai (GNNT) pada pertengahan Agustus 2014. Menurut beliau, GNNT ditujukan untuk meningkatkan kesadaran masyarakat terhadap penggunaan instrumen keuangan non tunai, yang jika diterapkan secara konsisten dalam jangka panjang akan terbentuk suatu komunitas/masyarakat pengguna instrumen non tunai (Less Cash Society)(Departemen Komunikasi Bank Indonesia, 2014).

Tabel 1. Transaksi Uang Elektronik di Indonesia tahun 2013-2017

\begin{tabular}{lll}
\hline Tahun & Nominal (Dalam Juta Rupiah) & Volume (Dalam Satuan Transaksi) \\
\hline 2013 & 2.907 .432 & 137.900 .779 \\
2014 & 3.319 .556 & 203.369 .990 \\
2015 & 5.283 .018 & 535.579 .528 \\
2016 & 7.063 .689 & 683.133 .352 \\
2017 & 12.375 .468 & 943.319 .933 \\
\hline
\end{tabular}

Sumber : Bank Indonesia, 2018

Berdasarkan data yang disajikan dapat kita simpulkan bahwa dari tahun 2013 sampai dengan tahun 2017, volume transaksi dengan menggunakan uang elektronik meningkat enam kali lipat. Sementara dari segi nominal, kenaikan total transaksi dari tahun 2013 sampai tahun 2017 mencapai tiga kali lipat dari jumlah transaksi tahun 2013. Kenaikan tersebut sebagian besar disebabkan oleh keluarnya Peraturan Menteri Pekerjaan Umum dan Perumahan Rakyat Republik Indonesia Nomor 16/PRT/M/2017 tentang Transaksi Tol Non Tunai di Jalan Tol yang menyatakan bahwa penerapan transaksi pembayaran tol non tunai sepenuhnya di seluruh jalan tol per 31 Oktober 2017.

Bank dan perusahaan financial technology dewasa initerus mengembangkan solusi yang inovatif dalam bertransaksi, baik untuk pembayaran ataupun penarikan uang tunai melalui ATM tanpa menggunakan kartu. Inovasi tersebut dilakukan untuk mengurangi tindakan sabotase dan mencegah teknik skimming pada mesin ATM atau pada mesin EDC (Electronic Data Capture) yang kerap terjadi dan meresahkan masyarakat(Fintechnews Singapore, 2017). Card skimming adalah aktivitas menggandakan informasi yang terdapat dalam pita magnetik (magnetic stripe) yang terdapat pada kartu kredit ataupun kartu debit secara ilegal(Aditya \& Susanto, 2017).

Kehadiran ponsel pintar banyak mengubah gaya hidup masyarakat dunia, tidak terkecuali di Indonesia. Segelintir pengguna ponsel pintar di Indonesia menyatakan bahwa lebih baik tidak membawa dompet dari pada tidak membawa ponsel pintar mereka. Hal itu disebabkan karena mulai berkembangnya layanan pembayaran dengan menggunakan dompet digital yang dapat diakses melalui ponsel pintar.

Merujuk pada Peraturan Bank Indonesia Nomor 18/40/PBI/2016 tentang Pemrosesan Transaksi Pembayaran, dompet elektronik atau electronic wallet adalah 
sebuah layanan elektronik untuk menyimpan data instrumen pembayaran antara lain alat pembayaran dengan menggunakan kartu dan/atau uang elektronik, yang dapat juga menampung dana untuk melakukan pembayaran(Bank Indonesia, 2016). Setiap penyelenggara dompet elektronik di Indonesia harus memiliki izin dari Bank Indonesia. Penyelenggaraan dompet elektronik diatur dalam Peraturan Bank Indonesia Nomor 20/6/PBI/2018 tentang Uang Elektronik. Dalam peraturan tersebut ditegaskan bahwa dalam penyelenggaraan uang elektronik di Indonesia harus dilakukan dengan prinsip-prinsip utama seperti penguatan perlindungan terhadap konsumen, pencegahan pencucian uang dan pendanaan kegiatan terorisme(Bank Indonesia, 2018).

Pembayaran menggunakan dompet elektronik pada gerai langsung, pelanggan harus memindai QR Code yang ada pada toko tersebut. Quick Response Code atau lebih sering disebut QR Code, merupakan salah satu jenis kode matriks atau kode batang dua dimensi. Walaupun sudah dikembangkan sejak 24 tahun silam, penggunaan QR Code untuk bertransaksi baru populer beberapa tahun belakangan. Penggunaan QR Code bertujuan untuk menyampaikan data yang terkandung di dalamnya dan merespons data tersebu tsecara cepat. QR Code mampu menyimpan informasi lebih banyak dan 10 kali lebih cepat dibandingkan dengan barcode. Hal tersebut menjadikan QR Code salah satu alat pembayaran yang efisien (Sang Ryu \& Murdock, 2013).

Cina menjadi salah satu negara yang sudah sukses menerapkan QR Code sebagai bagian dari sistem pembayaran di negaranya. Dua perusahaan pembayaran online di Cina, Alipay dan WeChat Payment, memulai debut pembayaran dengan QR Code di Cina. Kedua perusahaan tersebut menjalin kerja sama dengan perusahaan-perusahaan retail besar di Cina seperti, Carrefour dan Walmart. Kerja sama antara Alipay dan WeChat Payment dengan perusahaan retail tersebut, berdampak positif bagi kedua belah pihak. Dengan sistem pembayaran menggunakan QR Code, dapat mengurangi waktu pemrosesan pembayaran di kasir. Sehingga antrean panjang di kasir pada akhir pekan dan hari libur tidak lagi dijumpai(Xiaoyan, 2015). Hal tersebut dapat meningkatkan pelayanan supermarket tersebut. Setelah sukses dengan penerapan QR Code pada pembayaran di supermarket besar, belakangan ini QR Code telah digunakan untuk memberikan tip di restoran-restoran atau bahkan angpao pernikahan. Lebih mengejutkan lagi, pengemis-pengemis di Cina sudah menggunakan QR Codedalam kegiatannya sehari-hari(Chen, 2017).

Selain Cina, India juga sudah sukses menerapkan sistem pembayaran dengan menggunakan QR Code. Banyaknya pengguna smartphone di India menjadikan pembayaran dengan menggunakan QR Code menjadi lebih efektif. Pertumbuhan penggunaan QR Code sebagai metode pembayaran di India berlangsung pesat sama seperti yang terjadi di Cina. Menurut data dari Ministry of Electronics and Information Technology Government of India, sudah lebih dari 700.000 toko di India yang menggunakan Bharat QR per Oktober 2017(Economic Times, 2017). Bharat QR adalah solusi penerimaan pembayaran interoperable yang mendukung Visa, MasterCard, Amex dan RuPay \&BHIM UPI dalam penerimaan pembayaran yang lebih luas. Bharat QR memfasilitasi masyarakat India dalam melakukan pembayaran tanpa menggunakan kartu debit atau kredit 
secara fisik (Ministry of Electronics \& Information Technology Government of India, 2017).

Sejalan dengan gerakan pemerintah Indonesia dalam penggunaan uang non tunai, perusahaan perbankan ataupun non perbankan mulai mengembangkan sistem pembayaran dengan menggunakan QR Code. Salah satu bank swasta ternama di Indonesia, Bank Central Asia (BCA) meluncurkan aplikasi smartphone SAKUKU pada tahun 2015. Satu tahun setelahnya, tahun 2016, LippoX yang merupakan bagian dari Lippo Grup meluncurkan financial application OVO. Telkomsel yang sudah sejak tahun 2007 mengeluarkan fitur pembayaran dengan menggunakan uang digital yang diberi nama TCASH terus memperbaharui produknya. Pada tahun 2018, setelah mendapat izin dari Bank Indonesia, Telkomsel meresmikan TCASH dengan menggunakan QR Code. Pada tahun yang sama pula PT BNI Persero merilis aplikasi smartphone YAP! (Your All Payment) yang merupakan alat pembayaran non tunai tanpa menggunakan kartu fisik dan terhubung langsung dengan UnikQu dan debit serta credit card BNI. Selain BNI dan BCA, BRI juga sudah meluncurkan sistem pembayaran digital dengan menggunakan QR Code. BRI meluncurkan MY QR. Bedanya MY QR dapat digunakan oleh non-nasabah dari BRI. MY QR ditargetkan dapat menjangkau pasar menengah ke bawah, seperti pedagang di pasar tradisional. Baru-baru ini Bank Mandiri juga meluncurkan fitur permbayaran QR Code, dengan nama Mandiri Pay. Sama seperti MY QR, Mandiri Pay juga dapat digunakan oleh nonnasabah bank Mandiri. Perusahaan start up terbesar, Go-Jek atau PT Dompet Anak Bangsa juga sudah terlebih dahulu merilis Go-Pay untuk pembayaran transaksi pada aplikasi mereka. Namun, setelah mendapat izin dari Bank Indonesia pada April 2018, Go-Jek kembali merilis Go-Pay untuk transaksi di luar aplikasi dengan memanfaatkan QR Code. Izin Go-Pay sempat dibekukan penggunaannya oleh Bank Indonesia pada Februari 2018.

Penelitian ini mengacu pada penelitian (Farizi \& Syaefullah, 2013) mengenai pengaruh persepsi kegunaan, persepsi kemudahan, persepsi risiko dan kepercayaan terhadap minat menggunakan internet banking. Dari penelitian yang telah dilakukan dapat ditarik kesimpulan bahwa, persepsi kegunaan, persepsi risiko dan kepercaraan dapat memengaruhi minat pengguna dalam menggunakan internet banking. Sementara persepsi kemudahan penggunaan tidak memengaruhi minat dalam menggunakan internet banking. Penelitian lain serupa yang dilakukan oleh (Bangkara \& Mimba, 2016) menunjukkan hasil yang berbeda. Dari penelitian yang berjudul Pengaruh Perceived Usefulness dan Perceived Ease of Use pada Minat Penggunaan Internet Banking dengan Attitude Toward Using Sebagai Variabel Intervening dapat ditarik kesimpulan bahwa baik persepsi kegunaan maupun persepsi kemudahan penggunaan sama-sama berpengaruh positif terhadap minat penggunan internet banking.

Penelitian ini didukung dengan penelitian sebelumnya yang dilakukan oleh (Lo, 2014) yang berjudul Quick Response Code Around Us: Personality Traits, Attitudes towards Innovation and Acceptance menunjukkan bahwa late majority consumer, segmentasi konsumen yang menyikapi inovasi dengan tingkat skeptisme tinggi dan baru akan mengadopsi inovasi setelah mayoritas masyarakat lainnya telah mengadopsi inovasi tersebut (On Digital Marketing, 2016), memiliki sikap atau tanggapan yang tidak baik terhadap inovasi dan memiliki tingkat keinginan yang 
rendah dalam mengadopsi layanan QR Code. Dan sebaliknya, kelompok early majority customers dan adopters memiliki sikap dan tanggapan yang baik terhadap inovasi dan berkeinginan tinggi untuk mengadopsi layanan QR Code. Berdasarkan fenomena yang telah dipaparkan dan penelitian yang telah dilakukan sebelumnya, peneliti tertarik untuk mengetahui faktor-faktor yang memengaruhi minat mahasiswa S1 program studi akuntansi Fakultas Ekonomi dan Bisnis Universitas Udayana dalam mengadopsi QR Code dalam kegiatan transaksi sehari-hari.

Peneliti berpendapat bahwa transaksi keuangan dengan menggunakan QR Code, yang penggunaannya masih relatif baru di Indonesia, dapat berkembang pesat dan menjadi trend baru dalam bertransaksi. Selain itu, penelitian ini dilakukan untuk meningkatkan kesadaran mahasiswa program studi Akuntansi Fakultas Ekonomi dan Bisnis Universitas Udayana, bahwa sistem perekonomian, khususnya sistem pembayaran berkembang seiring berkembangnya zaman.Salah satu perkembangan perekonomian yang dapat kita rasakan sekarang adalah dengan adanya pengimplementasian sistem QR Code dalam transaksi keuangan. Dengan mengimplementasikan QR Code akan meningkatkan ketepatan waktu dalam pelaporan keuangan, karena data yang didapat real time. Selain itu pengimplementasian QR Code dapat mengefisiensikan waktu pada saat pembayaran di kasir, sehingga dapat meningkatkan pelayanan terhadap pelanggan.

Technology Acceptance Model (TAM) disusun berdasarkan dua teori-teori dasar mengenai model penerimaan teknologi yang telah dikembangkan sebelumnya, yaitu Theory of Reasoned Action (TRA) dan Theory of Planned Behavior (TPB). TRA pertama kali diperkenalkan tahun 1975 oleh Martin Fishbein dan Icek Ajzan . Teori ini disusun menggunakan asumsi bahwa manusia berperilaku dengan cara yang sadar dan mempertimbangkan segala informasi yang tersedia. Ajzen dan Fishbein dalam (Sayuti, 2012) berasumsi bahwa pengadopsian suatu teknologi pada umumnya ditentukan oleh proses kognitif dan bertujuan untuk memuaskan pemakainya atau memaksimalkan kegunaan teknologi itu sendiri.

TAM dikembangkan oleh Davis pada tahun 1989 dan tam Davis (1989) dalam (P.C.Lai \& Zainal, 2015)menjelaskan bahwa tujuan dari dikembangkannya teori TAM ini adalah untuk menjelaskan secara umum mengenai penerimaan teknologi yang mengarah pada penjelasan mengenai perilaku pengguna di berbagai pengembangan teknologi komputer. Berdasarkan TAM terdapat dua variabel utama yang memengaruhi penerimaan individu atas perkembangan teknologi dan sistem informasi yaitu, Perceived Usefulness (Persepsi Kegunaan) dan Perceived Ease of Use (Persepsi Kemudahan Penggunaan).

Persepsi kegunaan didefinisikan sebagai subjektivitas pengguna dalam menggunakan sebuah sistem aplikasi yang akan meningkatkan performa kerja atau kehidupannya. Sedangkan persepsi kemudahan penggunaan didefinisikan sebagai derajat apakah dalam menggunakan sistem aplikasi tersebut memerlukan usaha ekstra atau bahkan tidak diperlukan usaha sama sekali (Davis, 1989). Persepsi Kegunaan dan Persepsi Kemudahan Penggunaan dipengaruhi oleh variabel eksternal. Variabel eksternal yang dimaksud adalah, faktor sosial, faktor budaya dan faktor politik. Peningkatan Persepsi Kemudahan Penggunaan akan meningkatkan Persepsi Kegunaan. Hal tersebut disebabkan karena sebuah sistem 
yang mudah digunakan tidak akan membutuhkan waktu lama untuk dipelajari, sehingga efektivitas dalam bekerja dapat dimaksimalkan (Irmadhani, 2012). Pengembangan pada model TAM, dan menghasilkan TAM-2 dengan mengikutsertakan dua faktor luar, yaitu pengaruh sosial (social influence processes) sebagai variabel pertama dengan beberapa variabel yaitu, norma subjektif (subjective norm), voluntariness dan image. Variabel kedua adalah, instrumental kognitif (cognitive instrumental processes) dengan beberapa variabel seperti, job relevance, output quality, result demonstrability dan experience (Sayuti, 2012).

Persepsi Kegunaan merupakan sebuah persepsi individu yang percaya dengan menggunakan teknologi tertentu akan dapat meningkatkan prestasi kerja dirinya (Davis, 1989). Jogiyanto menegaskan bahwa Persepsi Kegunaan juga dikatakan sebagai suatu kepercayaan tentang proses pengambilan keputusan, maka dari itu jika seseorang percaya bahwa sebuah sistem informasi berguna, dia akan menggunakannya, sebaliknya apabila seorang percaya bahwa sebuah sistem informasi kurang berguna dia tidak akan menggunakannya (Az Zahra, 2018). Persepsi kegunaan menekankan pada hasil dari penggunaan sebuah teknologi. Persepsi kegunaan berkaitan dengan produktivitas dan efektivitas sistem dalam tugas secara menyeluruh untuk meningkatkan kinerja individu yang menggunakan sistem tersebut.

Persepsi Kemudahan Penggunaan merupakan derajat di mana individu percaya bahwa teknologi yang digunakan mudah untuk dipahami dan mudah digunakan. Kemudahan penggunaan dapat mengurangi usaha seseorang, baik waktu maupun tenaga, untuk mempelajari dan beradaptasi dengan sistem atau teknologi (Irmadhani, 2012).

Intensi merupakan sebuah indikasi seberapa banyak usaha yang dilakukan untuk menunjukkan suatu perilaku(Wardhana, 2016). Dengan kata lain, minat juga dapat didefinisikan sebagai kecenderungan ketertarikan pada sesuatu yang relatif tetap untuk lebih memperhatikan dan mengingat secara terus menerus yang diikuti rasa senang untuk memeroleh sebuah kepuasan dalam mencapai kepuasan penggunaan teknologi. Jogiyanto menekankan bahwa seseotang akan melakukan suatu perilaku jika mempunyai keinginan atau minat untuk melakukannya(Az Zahra, 2018). Apabila dalam menggunakan teknologi baru tersebut, pengguna merasa puas, maka pengguna tidak akan ragu untuk menggunakan teknologi tersebut secara berkelanjutan.

Perkembangan transaksi pembayaran dewasa ini yang bergerak menuju masyarakat non tunai merupakan tren yang tidak bisa dihindari. Hal tersebut sejalan dengan Gerakan Nasional Non Tunai (GNNT) yang diluncurkan pada pertengahan 2014. Namun pada kenyataannya transaksi retail di Indonesia masih didominasi dengan menggunakan uang tunai. Hal ini antara lain disebabkan masih banyaknya masyarakat yang belum memahami fungsi dan cara menggunakan instrumen non tunai serta masih banyaknya masyarakat di daerah yang belum terjangkau oleh layanan sistem pembayaran non tunai(Bank Indonesia, 2014). Masih mendominasinya transaksi menggunakan uang tunai menempatkan Indonesia pada step pertama berdasarkan kerangka Three Steps toward Electronic Payment,yaitu step transisi pembayaran massal, yang mengacu pada ketersediaan instrumen dan saluran pembayaran namun dalam penggunaannya masih sangat terbatas(Abbas, 2017). Untuk meningkatkan posisi 
Indonesia ke tahap kedua, yaitu tahap peningkatan penggunaan pembayaran elektronik, atau bahkan mempercepat perubahan menuju tahap ketiga, yaitu tahap sedikit transaksi menggunakan uang tunai, diperlukan strategi khusus (Bank Indonesia, 2014).

Menurut Peraturan Bank Indonesia tentang Uang Elektronik, yang dimaksud dengan Uang Elektronik atau electronic money adalah alat pembayaran yang diterbitkan atas dasar nilai uang yang disetor terlebih dahulu oleh pemegang kepada penerbit uang elektronik. Nilai uang yang disetor disimpan secara elektronik melalui media chip atau server. Nilai uang elektronik tersebut bukan merupakan simpanan atau tabungan, melainkan hanya dapat digunakan untuk bertransaksi (Bank Indonesia, 2009).

Penerapan pembayaran tanpa menggunakan uang elektronik banyak memberikan dampak positif yang dapat dirasakan pelakunya. Manfaat yang dapat dirasakan organisasi adalah pembayaran elektronik dapat memberikan kemudahan pekerjaan keuangan dan staf program dalam melakukan pembayaran kepada staf (gaji), pemasok, dan klien. Selain itu dengan menggunakan sistem pembayaran elektronik dapat meningkatkan transparansi transaksi dan meningkatkan efisiensi biaya(USAID, 2014). Hasil studi lain juga mengatakan bahwa pembayaran non tunai dapat meningkatkan pembayaran jarak jauh, mengurangi antrean (di kasir) dan dapat menghemat waktu. Tavares (2015) dalam (Abbas, 2017) menyatakan bahwa salah satu kekuatan utama dari pembayaran tanpa uang tunai adalah peningkatan basis pajak, karena semua transaksi dapat dilacak oleh pemerintah.

Di sisi lain, metode pembayaran tanpa menggunakan uang tunai juga akan menimbulkan masalah. Masalah terbesar yang timbul terkait dengan pembayaran non tunai adalah, masalah privasi. Brown dalam (Abbas, 2017) mengatakan bahwa pemerintah memiliki kekuatan yang substansial atas masyarakat dengan cara memiliki akses ke informasi pribadi masyarakat. Masalah privasi yang tidak kalah penting adalah para computer hacker. Para computer hacker dengan kemampuan yang dimilikinya dapat dengan mudah mengakses data pribadi pelanggan dan melakukan penyalahgunaan data. Untuk mengatasi masalah tersebut, pemerintah Indonesia melalui Bank Indonesia mengeluarkan peraturan No.11/12/PBI/2009 tentang Pengimplementasian Uang Elektronik. Sejalan dengan aturan tersebut, pemerintah mengharuskan para instansi penerbit uang elektronik mengganti pita magnetik (magnetic stripe) dengan basis chip.

Realisasi dari Less Cash Society sendiri pada dasarnya lebih mengarah pada perubahan budaya atau perilaku dan bukan hanya perubahan sistem. Untuk itu perubahan perilaku bertransaksi dari tunai ke non tunai harus dimulai dari lingkungan terkecil, yaitu diri sendiri, dan kemudian ke masyarakat luas. Maraknya penggunaan perangkat seluler belakangan ini, berdampak pada penerapan QR Code yang merambah ke berbagai industri, seperti industri perdagangan, pemasaran, logistik, pendidikan, pariwisata, hiburan dan lainlain(Albăstroiu \& Felea, 2015). Rouillard (2008) menjelaskan bahwa, keunggulan QR Code dari barcode pada umumnya adalah QR Code dapat menyimpan informasi baik secara vertikal maupun horizontal, sedangkan barcode biasa hanya dapat menyimpan satu arah data, biasanya data horizontal(Albăstroiu \& Felea, 2015). Hal ini menunjukkan bahwa lebih banyak informasi, baik berupa teks, 
angka maupun data biner, yang dapat disimpan oleh QR Code. Informasi yang disimpan secara vertikal dan horizontal dalam QR Code juga menyebabkan tempat yang dibutuhkan untuk mencetak QR Code empat kali lebih sedikit dibandingkan dengan tempat yang dibutuhkan untuk mencetak 1-D barcode (Singh, 2016).

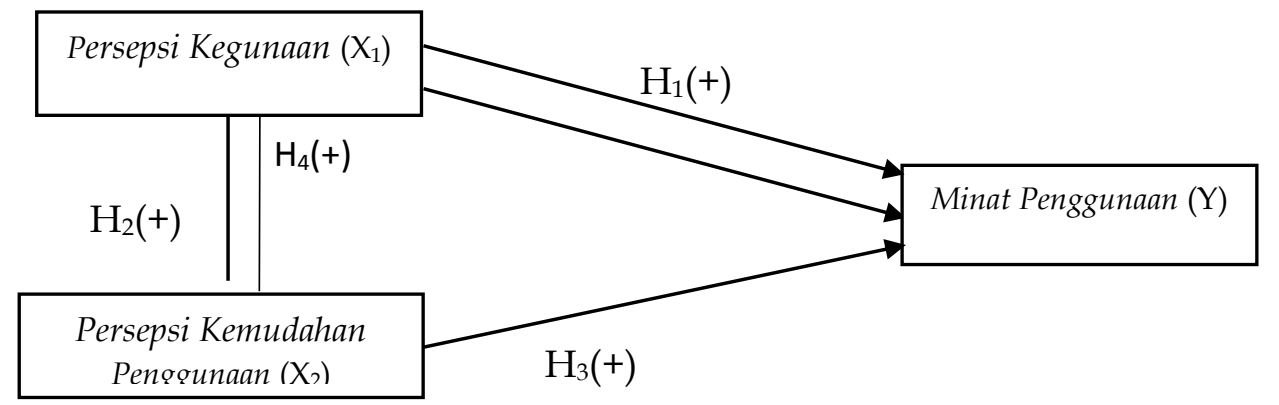

Gambar 1. Kerangka Konseptual Penelitian

Sumber : Data Penelitian, 2018

Penelitian yang dilakukan oleh (Farizi \& Syaefullah, 2013), (Andrie, 2012) dan (Bangkara \& Mimba, 2016) menunjukkan bahwa persepsi kegunaan berpengaruh positif terhadap minat pemanfaatan teknologi. Penelitian yang dilakukan oleh (Ozturk, 2016) mengenai penerimaan konsumen dalam penggunaan sistem pembayaran non tunai pada industri perhotelan juga menunjukkan bahwa persepsi kegunaan berpengaruh positif dan berdampak langsung dengan minat penggunaan pembayaran non tunai.

Dalam penelitian kali ini, persepsi kegunaan didefinisikan sebagai sejauh mana tingkat keyakinan pengguna bahwa dengan menggunakan Quick Response $(Q R)$ Code dapat menghemat waktu dan meningkatkan efektivitas dan efisiensi dalam proses pembayaran.

$\mathrm{H}_{1}$ : Terdapat pengaruh langsung Persepsi Kegunaan pada Minat Penggunaan

Peningkatan Persepsi Kemudahan Penggunaan akan meningkatkan Persepsi Kegunaan. Hal ini dikarenakan semakin tinggi keyakinan pengguna bahwa sistem atau teknologi tersebut mudah digunakan atau tidak memerlukan waktu lama untuk dipelajari maka akan mendukung pengguna dalam melakukan kegiatan sehari-hari. Dalam penelitian kali ini dikaji bagaimana pengaruh antara kemudahan penggunaan $Q R$ Code dalam meningkatkan persepsi kegunaan dalam penggunaan $Q R$ Code pada kehidupan sehari-hari.

$\mathrm{H}_{2}$ : Terdapat pengaruh langsung Persepsi Kemudahan penggunaan pada Persepsi Kegunaan

Hasil penelitian sebelumnya mengenai pengaruh persepsi kemudahan penggunaan terhadap minat penggunaan menunjukkan hasil yang beragam. Penelitian (Farizi \& Syaefullah, 2013) menunjukkan bahwa persepsi kemudahan penggunaan tidak berpengaruh terhadap minat menggunakan internet banking. Sementara penelitian (Irmadhani, 2012), (Andrie, 2012) dan (Bangkara \& Mimba, 2016), menunjukkan bahwa persepsi kemudahan penggunaan berpengaruh terhadap minat pemanfaatan teknologi. Walaupun masih menunjukkan hasil yang beragam dalam penelitian sebelumnya, namun penulis berkeyakinan bahwa persepsi kemudahan penggunaan berpengaruh langsung terhadap minat penggunaan sistem dan teknologi. Semakin sistem atau teknologi tersebut mudah 
digunakan (effortless) dan user friendly, maka semakin tinggi pula minat pengguna untuk menggunakan sistem tersebut. Hal tersebut karena, pengguna akan cenderung memilih sesuatu yang praktis dan mudah dipahami agar pekerjaan mereka selesai secara efektif dan efisien. Dalam penelitian kali ini, persepsi kemudahan penggunaan didefinisikan sebagai sejauh mana pengguna berkeyakinan bahwa dengan menggunakan QR Codedalam sistem pembayaran tidak akan membingungkan pengguna dan mudah dipahami.

$\mathrm{H}_{3}$ : Terdapat pengaruh langsung Persepsi Kemudahan Penggunaan pada Minat Penggunaan

Sementara persepsi kemudahan penggunaan dijelaskan sebagai suatu kepercayaan tentang proses pengambilan keputusan, jika seseorang merasa sistem tersebut mudah untuk digunakan maka mereka akan mengadopsi sistem tersebut. Oleh sebab itu, persepsi kemudahan penggunaan yang timbul akan meningkatkan keyakinan user atau pengguna bahwa sistem tersebut memiliki nilai guna dan pada akhirnya akan tertarik atau berminat menggunakan sistem tersebut.Intensitas penggunaan dari sebuah sistem atau teknologi juga mengindikasikan kemudahan penggunaan. Semakin sering sebuah sistem atau teknologi digunakan mengindikasikan bahwa sistem tersebut lebih dikenal dan dalam pengoperasiannya lebih mudah.

$\mathrm{H}_{4}$ : Terdapat pengaruh tidak langsung Persepsi Kemudahan Penggunaan pada Minat Penggunaan dengan Persepsi Kegunaan sebagai pemediasi.

\section{METODE PENELITIAN}

Penelitian ini menggunakan pendekatan kuantitatif berbentuk asosiatif. Penelitian ini dilakukan untuk mengetahui bagaimana persepsi mahasiswa terhadap metode pembayaran dengan menggunakan QR Code yang akan berpengaruh pada minat mereka untuk mengadopsi metode tersebut dalam melakukan transaksi keuangan mereka sehari-hari.

Lokasi penelitian dalam penelitian ini adalah di Kota Denpasar dan Bukit Jimbaran, lebih tepatnya pada Fakultas Ekonomi dan Bisnis Universitas Udayana. Objek penelitian ini adalah minat penggunaan mahasiswa-mahasiswi S1 program studi akuntansi Fakultas Ekonomi dan Bisnis Universitas Udayana dalam menggunakan $Q R$ Code saat bertransaksi. Hal tersebut dikarenakan, mahasiswa sebagai generasi muda dianggap sebagai generasi yang paling terbuka dalam menerima sistem atau teknologi baru, yang dalam penelitian ini adalah penggunaan $Q R$ Codedalam transaksi keuangan.

Penelitian kali ini hanya dibatasi dalam lingkup mahasiswa program studi S1 Akuntansi saja karena mahasiswa akuntansi perlu menyadari bahwa perkembangan teknologi yang marak belakangan inisangat berpengaruh pada perkembangan akuntansi. Hal ini karena dengan penggunaan $Q R$ Code dapat meningkatkan ketepatan waktu dalam pelaporan keuangan, mengingat dengan penggunaan $Q R$ Code informasi keuangan yang disampaikan secara real time.

Penelitian kali ini penulis menjadikan persepsi kemudahan penggunaan sebagai variabel eksogen. Variabel Mediasi adalah variabel perantara antara variabel independen atau variabel bebas dengan variabel terikat atau variabel dependen. Dalam penelitian kali ini penulis menjadikan persepsi kegunaan 
sebagai variabel pemediasi. Dalam penelitian ini penulis menjadikan persepsi kegunaan dan minat penggunaan sebagai variabel endogen.

Populasi dalam penelitian ini adalah mahasiswa Program Studi Akuntansi Fakultas Ekonomi dan Bisnis Universitas Udayana, yang meliputi mahasiswa reguler dan non-reguler. Penelitian ini dilakukan pada mahasiswa aktif empat angkatan terakhir dimulai dari angkatan 2015, 2016, 2017 dan 2018. Hal ini dilakukan dengan asumsi, semakin besar dan beragam jumlah objek yang diamati, maka hasil penelitian yang didapatkan dapat lebih akurat dan representatif. Penelitian kali ini populasi penelitian yang mencakup seluruh mahasiswamahasiswi aktif S1 program studi Akuntansi Fakultas Ekonomi dan Bisnis Universitas Udayana baik yang berkuliah di Denpasar maupun yang berkuliah di kampus Jimbaran. Keseluruhannya berjumlah 1.115 orang.

Teknik sampling yang digunakan dalam penelitian ini adalah non-probability sampling. Metode pengambilan sampel yang digunakan dalam penelitian ini adalah dengan metod esampling insidental. Pertimbangan peneliti dalam memperhitungkan apakah calon responden layak dijadikan sampel mengacu pada kriteria yang sudah peneliti tetapkan. Kriteria yang digunakan dalam penelitian kali ini adalah responden merupakan mahasiswa aktif program studi Akuntansi Fakultas Ekonomi dan Bisnis Universitas Udayana angkatan 2015, 2016, 2017 dan 2018. Responden pernah melakukan transaksi dengan menggunakan dompet elektronik pada gerai langsung dengan menggunakan QR Code. Menentukan sampel yang dapat menggambarkan populasi, maka sampel ditentukan dengan menggunakan rumus Slovin. Formula yang digunakan adalah: $n=\frac{N}{N(e)^{2}+1}$.

Keterangan :

$\mathrm{n}=$ Jumlah Sampel

$\mathrm{N}=$ Ukuran Populasi

$\mathrm{e}=$ Batas error yang ditolerir, dalam penelitian ini sebesar $5 \%$ atau 0,05 .

Dalam penelitian kali ini populasi yang peneliti gunakan adalah sebanyak 1.115 orang. Oleh karena itu dengan perhitunganmenggunakan rumus slovin mendapatkan jumlah sampel sebanyak 294 mahasiswa. Berikut merupakan perhitungannya.

$$
\begin{aligned}
& n=\frac{1.115}{1.115(0,05)^{2}+1} \\
& n=294,2 \approx 294
\end{aligned}
$$

Metode pengumpulan data yang digunakan dalam penelitian ini adalah dengan menggunakan kuesioner dan melakukan wawancara. Teknik wawancara digunakan peneliti untuk mengetahui alasan responden lebih terperinci terkait dengan jawaban responden. Teknik wawancara yang digunakan adalah wawancara tak berstruktur.

Data dalam penelitian ini yang digunakan merupakan data kuantitatif. Data kuantitatif tersebut diperoleh dari hasil kuesioner yang berupa pernyataan responden dan kemudian data tersebut dirubah menjadi skala angka. Dalam penelitian ini data primer yang diperoleh meliputi jawaban dari kuesioner yang disebarkan oleh peneliti. Data sekunder yang diperoleh meliputi jumlah 
mahasiswa-mahasiswi program studi Akuntansi FEB Universitas Udayana angkatan 2015, 2016, 2017 dan 2018 yang masih terdaftar menjadi mahasiswa aktif.

\section{HASIL DAN PEMBAHASAN}

Penelitian ini responden yang dibutuhkan adalah mahasiswa aktif program studi Akuntansi Fakultas Ekonomi dan Bisnis Universitas Udayana angkatan 2015, 2016, 2017 dan 2018. Menurut data yang dihimpun dari bagian kemahasiswaan Fakultas Ekonomi dan Bisnis Universitas Udayana, jumlah mahasiswa Program Studi Akuntansi baik perkuliahan di Bukit maupun di Denpasar berjumlah 1.115 orang, dengan rincian sebagai berikut.

Tabel 2. Mahasiswa Aktif Program Studi Akuntansi FEB UNUD Angkatan 20152018

\begin{tabular}{llll}
\hline Tahun & Reguler (Bukit) & Non-Reguler(Denpasar) & Total \\
\hline 2015 & 142 & 133 & 275 \\
2016 & 167 & 135 & 302 \\
2017 & 150 & 138 & 288 \\
2018 & 250 & & 250 \\
TOTAL & & & 1115 \\
\hline
\end{tabular}

Sumber: Bagian Akademik FEB UNUD, 2018

Peneliti menyebarkan kuesioner kepada mahasiswa aktif Program Studi Akuntansi Fakultas Ekonomi dan Bisnis Universitas Udayana mulai dari angkatan 2015 sampai dengan angkatan 2018.

Tabel 3. Jumlah Kuesioner yang Memenuhi Syarat

\begin{tabular}{lll}
\hline Keterangan & Jumlah & $\%$ \\
\hline Kuesioner yang disebar & 334 & 100 \\
Kuesioner yang kembali & 334 & 100 \\
Kuesioner yang tidak memenuhi kriteria & 40 & 11,9 \\
Kuesioner yang memenuhi kriteria & 294 & 88,0 \\
\hline
\end{tabular}
Sumber : Data Penelitian, 2018

Dapat dilihat pada Gambar 2. hampir setengah atau $42 \%$ dari jumlah responden merupakan angkatan 2015. Disusul angkatan 2017 sebesar 21\% dan angkatan 2016 dan 2018 masing-masing sebesar 19\% dan 18\%.

\section{Sebaran Responden Berdasarkan Angkatan

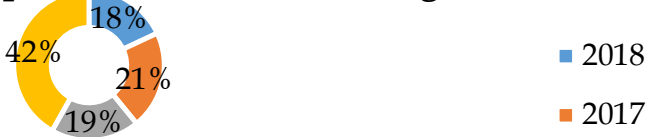

Gambar 2. Grafik Sebaran Responden berdasarkan Angkatan

Sumber : Data Penelitian, 2018

Gambar 3 menampilkan sebaran responden berdasarkan dimpet elektronik yang digunakan dengan hamir 45\% dengan menggunakan Go-Pay dari jumlah responden 18\% menggunakan T-CASH Wallet, 26\% menggunakan OVO, $5 \%$ menggunakan YAP!, 4\% menggunakan SAKUKU dan 2\% sisanya menggunakan aplikasi dompet elektronik yang berbeda. 


\section{Sebaran Responden berdasarkan Dompet Elektronik yang

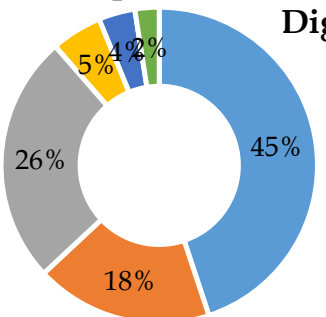 \\ - GO-PAY by GO-JEK \\ - T-CASH WALLET by TELKOMSEL \\ - OVO \\ - YAP! By BNI \\ - SAKUKU by BCA}

\section{Gambar 3. Grafik Sebaran Responden berdasarkan Dompet Elektronik yang digunakan}

Sumber : Data Penelitian, 2018

Dapat disimpulkan dari Gambar 3 bahwa mayoritas dari responden memanfaatkan layanan Go-Pay dari Go-Jek dan OVO dalam bertransaksi menggunakan dompet elektronik.

Analisis statistik deskriptif disajikan untuk memberikan informasi tentang karakteristik variabel penelitian. Indikator statistik yang digunakan dalam penelitian ini adalah mean dan standar deviasi. Nilai rata-rata (mean) merupakan nilai rata-rata dari setiap variabel yang diteliti.

\section{Tabel 4. Hasil Uji Statistik Deskriptif}

\begin{tabular}{|c|c|c|c|c|c|}
\hline Variabel & $\begin{array}{l}\text { Nilai } \\
\text { Minimum }\end{array}$ & $\begin{array}{l}\text { Nilai } \\
\text { Maksimum }\end{array}$ & $\mathrm{N}$ & Mean & $\begin{array}{l}\text { Standar } \\
\text { Deviasi }\end{array}$ \\
\hline $\begin{array}{ll}\text { Persepsi } & \text { Kegunaan } \\
\left(X_{1}\right) & \end{array}$ & 8 & 40 & 294 & 34,41 & 4,520 \\
\hline $\begin{array}{l}\text { Persepsi Kemudahan } \\
\text { Penggunaan }\left(X_{2}\right)\end{array}$ & 8 & 40 & 294 & 34,46 & 4,741 \\
\hline Minat Penggunaan $(\mathrm{Y})$ & 4 & 20 & 294 & 16,90 & 2,840 \\
\hline
\end{tabular}

Sumber : Data Penelitian, 2018

Hasil pengujian statistik deskriptif terhadap persepsi kegunaan menunjukkan nilai rata-rata sebesar 34,41 dengan standar deviasi sebesar 4,520. Nilai rata-rata sebesar 34,41 menunjukkan bahwa persepsi responden terhadap persepsi kegunaan $Q R$ Code berada dalam skala 5. Hal ini bermakna penggunaan $Q R$ Code dirasa responden sangat berguna.

Hasil pengujian statistik deskriptif terhadap Persepsi Kemudahan Penggunaan menunjukkan nilai rata-rata sebesar 34,46 dengan standar deviasi sebesar 4,741 Nilai rata-rata sebesar 34,46 menunjukkan bahwa persepsi responden terhadap persepsi kemudahan penggunaan $Q R$ Code berada juga dalam skala 5. Hal ini bermakna penggunaan $Q R$ Code dirasa responden sangat mudah.

Hasil pengujian statistik deskriptif terhadap Persepsi Minat Penggunaan menunjukkan nilai rata-rata sebesar 16,90 dengan standar deviasi sebesar 2,840. Nilai rata-rata sebesar 16,90 menunjukkan bahwa persepsi responden terhadap persepsi kemudahan penggunaan $Q R$ Code berada juga dalam skala 5 . Hal ini bermakna bahwa responden sangat berminat menggunakan $Q R$ Code.

Tabel 5. Tabel Nilai Loading Factor Indikator

\begin{tabular}{lllc}
\hline & & & Estimate \\
\hline X1.1 & $<---$ & Persepsi_Kegunaan & .769 \\
X1.2 & $<--$ & Persepsi_Kegunaan & .682 \\
\hline
\end{tabular}

Bersambung ... 
Lanjutan Tabel 5.

\begin{tabular}{llll}
\hline X1.3 & $<---$ & Persepsi_Kegunaan & .715 \\
X1.4 & $<--$ & Persepsi_Kegunaan & .658 \\
X1.5 & $<---$ & Persepsi_Kegunaan & .642 \\
X1.6* & $<--$ & Persepsi_Kegunaan & .493 \\
X1.7 & $<---$ & Persepsi_Kegunaan & .807 \\
X1.8 & $<---$ & Persepsi_Kegunaan & .801 \\
X2.16 & $<--$ & Persepsi_Kemudahan & .557 \\
X2.15 & $<---$ & Persepsi_Kemudahan & .790 \\
X2.14 & $<---$ & Persepsi_Kemudahan & .766 \\
X2.13 $<---$ & Persepsi_Kemudahan & .804 \\
X2.12 & $<---$ & Persepsi_Kemudahan & .772 \\
X2.11 $<---$ & Persepsi_Kemudahan & .788 \\
X2.10 & $<---$ & Persepsi_Kemudahan & .748 \\
X2.9 $<---$ & Persepsi_Kemudahan & .811 \\
Y.17 & $<---$ & Minat_Penggunaan & .851 \\
Y.18 & $<---$ & Minat_Penggunaan & .668 \\
Y.19 $<---$ & Minat_Penggunaan & .806 \\
Y.20 & $<---$ & Minat_Penggunaan & .795 \\
\hline
\end{tabular}

Sumber : Data Penelitian, 2018

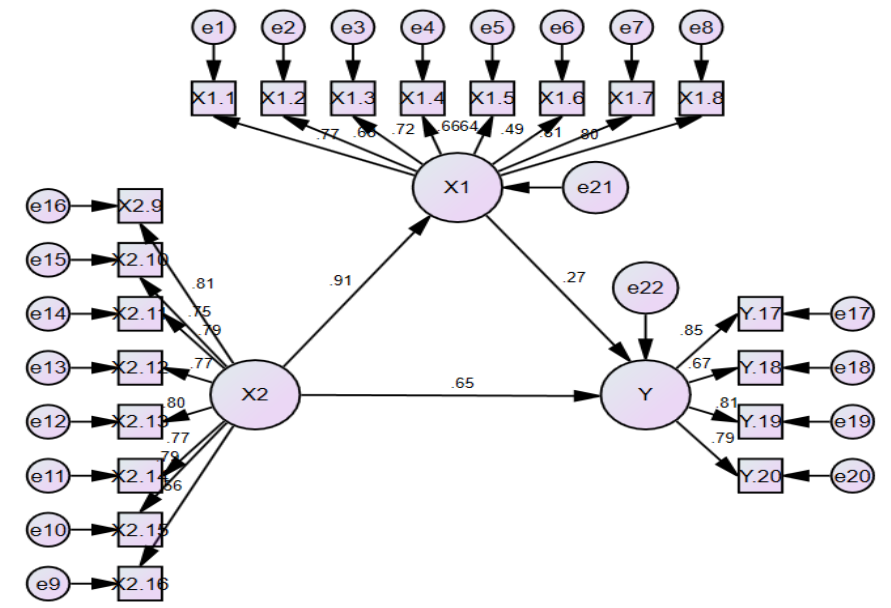

Gambar 4. Diagram Jalur Hubungan Kausalitas Penelitian Sebelum Re-Etimasi Sumber : Data Penelitian, 2018

Keterangan :

X1 : Persepsi Kegunaan

X2 : Persepsi Kemudahan Penggunaan

Y : Minat Penggunaan

Berdasarkan Tabel 5 indikator X1.6 dinyatakan tidak valid. Hal ini dilihat dari nilai loading factor 0,493 atau di bawah nilai syarat loading factor sebesar 0,5. Sehingga harus dilakukan estimasi ulang dengan menghilangkan X1.6. Sedangkan Gambar 4. menunjukkan diagram jalur yang menunjukkan nilai outer loading factor dengan konstruk sebelum re-estimasi untuk menghilangkan indikator X1.6. 
Tabel 6. Nilai Loading Factor Indikator setelah re-estimasi

\begin{tabular}{llll}
\hline & & & Estimate \\
\hline X1.1 & $<---$ & Persepsi_Kegunaan & .775 \\
X1.2 & $<---$ & Persepsi_Kegunaan & .685 \\
X1.3 & $<--$ & Persepsi_Kegunaan & .726 \\
X1.4 & $<---$ & Persepsi_Kegunaan & .656 \\
X1.5 & $<--$ & Persepsi_Kegunaan & .634 \\
X1.7 & $<---$ & Persepsi_Kegunaan & .814 \\
X1.8 & $<---$ & Persepsi_Kegunaan & .797 \\
X2.16 $<---$ & Persepsi_Kemudahan & .554 \\
X2.15 & $<---$ & Persepsi_Kemudahan & .790 \\
X2.14 & $<---$ & Persepsi_Kemudahan & .766 \\
X2.13 & $<---$ & Persepsi_Kemudahan & .804 \\
X2.12 & $<---$ & Persepsi_Kemudahan & .772 \\
X2.11 $<---$ & Persepsi_Kemudahan & .789 \\
X2.10 $<---$ & Persepsi_Kemudahan & .749 \\
X2.9 $<---$ & Persepsi_Kemudahan & .811 \\
Y.17 & $<---$ & Minat_Penggunaan & .851 \\
Y.18 & $<---$ & Minat_Penggunaan & .668 \\
Y.19 & $<--$ & Minat_Penggunaan & .806 \\
Y.20 & $<---$ & Minat_Penggunaan & .796 \\
\hline
\end{tabular}

Sumber : Data Penelitian, 2018

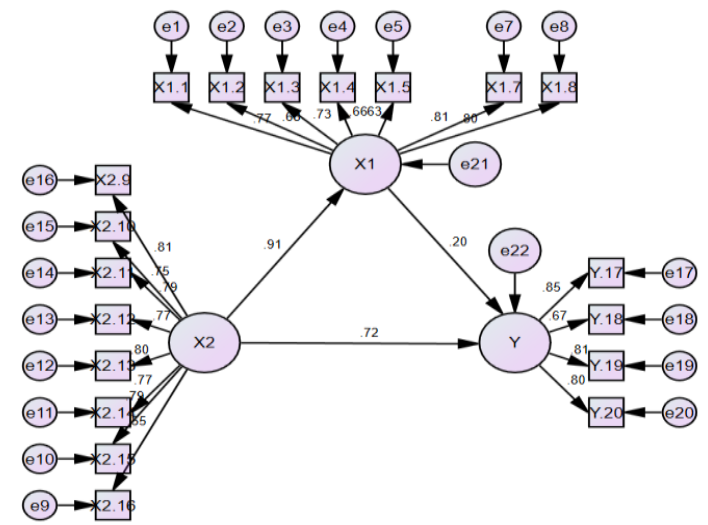

Gambar 5. Diagram Jalur Hubungan Kausalitas Penelitian setelah re-etimasi

Sumber : Data Penelitian, 2018

Keterangan :

X1 : Persepsi Kegunaan

X2 : Persepsi Kemudahan Penggunaan

Y : Minat Penggunaan

Setelah dilakukan estimasi ulang diperoleh hasil yang disajikan pada Tabel 6. Hasil re-estimasi menunjukkan semua indikator bernilai lebih besar dari 0,5, yang artinya semua indikator dinyatakan valid dan model dapat dilanjutkan. Gambar 5. menunjukkan diagram jalur setelah dilakukan re-estimasi. 
Tabel 7. Nilai Critical Ratio

\begin{tabular}{lll}
\hline Konstruk & VE & Keterangan \\
\hline Persepsi_Kegunaan & 0.6759 & Reliabel \\
Persepsi_Kemudahan & 0.6862 & Reliabel \\
Minat_Penggunaan & 0.6860 & Reliabel \\
\hline
\end{tabular}

Sumber : Data Penelitian, 2018

Berdasarkan hasil perhitungan, tidak ada nilai variance extracted yang di bawah 0,50. Hal tersebut mengindikasikan bahwa semua konstruk dalam penelitian ini reliabel dan layak digunakan dalam model.

Tabel 8. Indeks Kriteria Goodnes of Fit

\begin{tabular}{llll}
\hline Kriteria & Hasil & Nilai kritis & Kesimpulan \\
\hline p-value & 0.000 & $\geq 0,05$ & Not fit \\
RMSEA & 0.056 & $\leq 0,08$ & Good fit \\
GFI & 0.903 & $\geq 0,90$ & Good fit \\
AGFI & 0.876 & $\geq 0,90$ & maginal fit \\
CMIN/DF & 1.905 & $\leq 2,00$ & Good fit \\
TLI & 0.957 & $\geq 0,95$ & Good fit \\
CFI & 0.962 & $\geq 0,95$ & Good fit \\
\hline
\end{tabular}

Sumber : Data Penelitian, 2018

Berdasarkan hasil pengujian goodness-of-fit pada Tabel 8. maka dapat disimpulkan bahwa model yang dihasilkan merupakan model yang good fit. Dengan kata lain model dapat diterima sebagai model penelitian.

Tabel 9. Hasil Pengujian Hipotesis

\begin{tabular}{llllllll}
\hline & & & Estimate & S.E. & C.R. & P & Label \\
\hline $\begin{array}{l}\text { Persepsi_ } \\
\begin{array}{l}\text { Megunaan } \\
\text { Minat_Pe }\end{array}\end{array}$ & $<--$ & Persepsi_Kemudahan & .875 & .094 & 9.259 & $* * *$ & Signifikan \\
$\begin{array}{l}\text { nggunaan } \\
\text { Minat_Pe } \\
\text { nggunaan }\end{array}$ & $<--$ & Persepsi_Kemudahan & .865 & .167 & 5.194 & $* * *$ & Signifikan \\
\hline
\end{tabular}

Sumber : Data Penelitian, 2018

Berdasarkan Tabel 9. dapat ditarik kesimpulan sebagai berikut. Terdapat pengaruh langsung antara persepsi kemudahan penggunaan pada persepsi kegunaan sebesar 0,875. Artinya semakin meningkatnya persepsi kemudahan penggunaan juga akan meningkatkan persepsi kegunaan. Tidak terdapat pengaruh langsung antara persepsi kegunaan pada minat penggunaan. Terdapat pengaruh langsung antara persepsi kemudahan penggunaan pada minat penggunaan sebesar 0,865. Artinya semakin meningkatnya persepsi kemudahan juga akan meningkatkan minat penggunaan.

Suatu variabel mediasi akan berpengaruh jika nilai $t$ hitung lebih besar dari $\mathrm{t}$ tabel dengan $a=5 \%$ yaitu 1,64. T hitung dapat diperoleh dengan menggunakan pengujian Sobel atau Sobel Test.

$$
\begin{aligned}
& t=\frac{a b}{s_{a b}} \\
& S_{a b}=\sqrt{b^{2} S_{a}^{2}+a^{2} S_{b}^{2}+S_{a}^{2} S_{b}^{2}} \text {. }
\end{aligned}
$$

Perhitungan standart error gabungan ab diperoleh :

$$
\text { a }=0,875 \quad S_{a}=0,094
$$


$\mathrm{b} \quad=0,253 \quad S_{b}=0,152$

$S_{a b}=0,1359$

$t=\frac{(0.875)(0.253)}{0.1359}=1.6294$

Berdasarkan perhitungan di atas diperoleh nilai t sebesar 1,629. Sehingga dapat disimpulkan bahwa tidak terdapat pengaruh antara persepsi kemudahan penggunaan pada minat penggunaan melalui persepsi kegunaan sebagai pemediasi.

\section{SIMPULAN}

Berdasarkan hasil penelitian mengenai pengaruh persepsi kegunaan dan persepsi kemudahan penggunaan pada minat penggunaan Quick Response Code dalam transaksi keuangan studi kasus pada mahasiswa program studi Akuntansi Fakultas Ekonomi dan Bisnis Universitas Udayana, dapat disimpulkan bahwa variabel persepsi kegunaan tidak berpengaruh langsung pada minat penggunaan. Hal ini berarti seseorang tidak terlalu mementingkan nilai kegunaan dari sebuah sistem atau teknologi baru, dalam penelitian ini adalah QR Code.

Variabel persepsi kemudahan penggunaan memiliki pengaruh langsung pada persepsi kegunaan. Hal ini berarti semakin meningkatnya persepsi seseorang akan semakin mudahnya sebuah sistem atau teknologi baru, dalam penelitian ini adalah QR Code.Variabel persepsi kemudahan memiliki pengaruh langsung pada minat penggunaan. Hal ini berarti semakin meningkatnya persepsi kemudahan penggunaan yang dirasakan seseorang dalam menggunakan sebuah sistem atau teknologi baru, dalam penelitian ini adalah QR Code. Variabel persepsi kemudahan penggunaan tidak berpengaruh pada minat penggunaan dengan persepsi kegunaan sebagai pemediasi. Hal ini berarti persepsi kemudahan penggunaan yang timbul tidak meningkatkan keyakinan pengguna akan nilai guna dari penggunaan QR Code dalam transaksi keuangan.

Berdasarkan simpulan dan keterbatasan penelitian, maka saran yang dapat diberikan oleh peneliti. Bagi mahasiswa merupakan genarasi muda yang berperan besar sebagai agen perubahan, sudah sebaiknya menerapkan pembayaran dengan menggunakan uang elektronik baik berupa kartu maupun dompet elektronik secara konsisten agar sistem pembayaran di Indonesia dapat mengikuti arus perkembangan pembayaran di dunia.

Bagi Para penyedia uang elektronik diharapkan dapat terus mengembangkan dan memperbaiki layanan uang elektronik agar dapat digunakan di seluruh Indonesia. Peneliti selanjutnya juga diharapkan dapat melakukan penelitian pada sampel yang berbeda ataupun dengan metode yang berbeda, misalnya dengan menggunakan teknik wawancara.

\section{REFERENSI}

Abbas, A. E. (2017). Literature Review of a Cashless Society in Indonesia: Evaluating the Progress. International Journal of Innovation, Management and Technology, 8(3), 193-196. https://doi.org/10.18178/ijimt.2017.8.3.727

Aditya, N. F., \& Susanto, A. F. (2017). Pembobolan ATM Melalui Teknik Skimming Dihubungkan dengan UU No. 19 tahun 2016 tentang Perubahan atas UU No. 11 
tahun 2008 tentang Informasi dan Transaksi Elektronik.Institusional Respositories $\mathcal{E}$ Scientific Journals Pasundan University. Bandung.

Andrie, S. (2012). Kemudahan, dan Persepsi Risiko Terhadap Perilaku Penggunaan E-Commerce. Jurnal Ilmiah Mahasiswa FEB Universitas Brawijaya, 1(2), 1-20.

Anggraeni, Rila. (2015). Pengaruh Persepsi Kemudahan Penggunaan dan Persepsi

Kegunaan terhadap Niat untuk Menggunakan dan Penggunaan Aktual Layanan Jejaring Sosial Berbasis Lokasi (Studi pada Mahasiswa Fakultas Ekonomi dan Bisnis Universitas Brawijaya Malang). Jurnal Ekobis 20(1).

Az Zahra, F. (2018). Pengaruh Perceived Usefulness, Perceived Ease of Use dan Perceived Risk terhadap Intention to Shop Online. Jurnal Ilmiah Mahasiswa FEB Universitas Brawijaya, 7(1)

Bangkara, R. P., \& Mimba, N. P. S. H. (2016). Pengaruh Perceived Usefulness Dan Perceived Ease Of Use Pada Minat Penggunaan Internet Banking Dengan Attitude Toward Using Sebagai Variabel Intervening. Jurnal Akuntansi Universitas Udayana. https:/ / doi.org/10.1088/0031-9155/47/24/301

Bank Indonesia. Peraturan Bank Indonesia Nomor 11/12/PBI/2009 tentang Uang Elektronik, Pub. L. No. 11/12/PBI/ 2009 (2009).

Bank Indonesia. (2014). Gaya Hidup Masa Kini: Minim Uang Tunai. Bank Indonesia. Retrieved from www.bi.go.id/.../geraiinfo/Documents/GeraiInfoBI_5014.pdf

Bank Indonesia. Peraturan Bank Indonesia Nomor 18/40/PBI/2016 tentang Pemrosesan Transaksi, Pub. L. No. 18/40/PBI/2016 (2016).

Bank Indonesia. Peraturan Bank Indonesia Nomor 20/6/PBI/2018 tentang Uang Elektronik, Pub. L. No. 20/6/PBI/2018 (2018).

Chen, S. (2017). The Rise of the QR Code and How It Has Forever Changed China's Social Habits. South China Morning Post. Retrieved from https://www.scmp.com/news/china/society/article/2095576/rise-qrcode-and-how-it-has-forever-changed-chinas-social-habits

Davis, F. D. (1989). Perceived Usefulness, Perceived Ease of Use, and User Acceptance of Information Technology. MIS Quarterly. https:// doi.org/10.2307/249008

Departemen Komunikasi Bank Indonesia. (2014). Bank Indonesia Mencanangkan Gerakan Nasional Non Tunai (GNNT). Retrieved from https://www.bi.go.id/id/ruang-media/siaran-pers/Pages/sp_165814.aspx

Economic Times. (2017). One Nation, Under Code: How India Leads the Way in the Interoperability of QR Code for Payments. The Economic Times. Retrieved from

https://economictimes.indiatimes.com/industry/banking/finance/bankin $\mathrm{g} /$ one-nation-under-code-how-india-leads-the-way-in-the-interoperabilityof-qr-code-for-payments/articleshow/60986772.cms

Farizi, H., \& Syaefullah. (2013). Pengaruh Persepsi Kegunaan, Persepsi Kemudahan, Persepsi Risiko Dan Kepercayaan Terhadap Minat Menggunakan Internet Banking. Jurnal Ilmiah Mahasiswa FEB, 2(1), 1-18. https://doi.org/10.1017/CBO9781107415324.004

Fintechnews Singapore. (2017). Going Cardless and Cashless: How Banks and Fintechs are Reinventing Payments. Fintechnews Singapore. Retrieved from 
http:/ / fintechnews.sg/9298/mobilepayments/going-cardless-cashlessbanks-fintechs-reinventing-payments/

Irmadhani. (2012). Pengaruh Persepsi Kebermanfaatan, Persepsi Kemudahan Penggunaan dan Computer Self Efficacy, Terhadap Penggunaan Online Banking pada Mahasiswa S1 Fakultas Ekonomi Universitas Negeri Yogyakarta. Journal UNY.

Lai, P. (2017). The Literature Review Of Technology Adoption Models And Theories For The Novelty Technology. Journal of Information Systems and Technology Management. https:/ / doi.org/10.4301/S1807-17752017000100002

Lai, P. C., \& Zainal, A. A. (2015). Perceived Enjoyment and Malaysian Consumers' Intention to Use a Single Platform E-Payment. SHS Web of Conferences. https://doi.org/10.1051/shsconf/20151801009

Lo, H. (2014). Quick Response Codes Around Us: Personality Traits, Attitudes Toward Innovation, And Acceptance. Journal of Electronic Commerce Research.

Ministry of Electronics \& Information Technology Government of India. (2017). Bharat QR. Retrieved from http:// meity.gov.in/bharat-qr-code

Ozturk, A. B. (2016). Customer acceptance of cashless payment systems in the hospitality industry. International Journal of Contemporary Hospitality Management. https:/ / doi.org/10.1108/IJCHM-02-2015-0073

Sang Ryu, J., \& Murdock, K. (2013). Consumer acceptance of mobile marketing communications using the QR code. Journal of Direct, Data and Digital Marketing Practice. https:// doi.org/10.1057/dddmp.2013.53

Sayuti. (2012). Kajian Efektivitas Penerimaan dan Penggunaan Metode Pembelajaran Berbasis Blended e-Learning (Studi Kasus pada Fakultas Ilmu Komputer UPN "Veteran" Jakarta. Budi Luhur University.

Singh, S. (2016). QR Code Analysis. International Journal of Advanced Research in Computer Science and Software Engineering, 6(5). https:// doi.org/10.1021/jp3113073

Sugiyono. (2017). Metode Penelitian Kuantitatif dan Kualitatif dan RED. Bandung: Alfabeta.

Tjini, Sartika Sari A., Baridwan Zaki. (2013). Pengaruh Kepercayaan, Persepsi Kegunaan, Persepsi Kemudahan dan Persepsi Kenyamanan terhadap Minat Penggunaan Sistem Internet Banking, Jurnal Ilmiah Mahasiswa FEB Universitas Brawijaya, 1(2)

USAID. (2014). Making the Journey from Cash to Electronic Payments. Retrieved from

https://www.usaid.gov/sites/default/files/documents/15396/USAID_Ne t\%0AHope_ePayment_Toolkit_2016.pdf

Wardhana, O. H. P. (2016). Pengaruh Persepsi Kemudahan, Persepsi Kegunaan, Persepsi Nilai, Pengaruh Soosial, Persepsi Resiko dan Kepercayaan terhadap Minat menggunakan E-Commerce. Jurnal Ilmiah Mahasiswa FEB Universitas Brawijaya, 4(2).

Xiaoyan, Z. (2015). A Change in Pay. Beijing Review. Retrieved from A Change in Pay. 